\title{
Effectiveness of Learning Package on Weaning Practices among Primipara Mothers
}

\author{
Hemant Kumar Tak ${ }^{1}$, Dharmesh Chaturvedi ${ }^{2}$ \\ ${ }^{1}$ Principal, MASS College of Nursing, Udaipur, Rajasthan, India \\ ${ }^{2} \mathrm{Ph} . \mathrm{D}$. Nursing Scholar, Sai Tirupati University, Udaipur, Rajasthan, India \\ Corresponding Author: Dharmesh Chaturvedi
}

DOI: https://doi.org/10.52403/ijhsr.20220131

\begin{abstract}
Background: As primipara mothers are unaware about the quantity and quality of the complimentary foods, poor child's feeding practices and high rates of infections causing ill effects to health and growth in period of infancy. Therefore, present study aims to improve knowledge of primipara mothers by giving them learning package on weaning practices.

Method: Quantitative true experimental research design was used to conduct study. A sample of 60 primipara mothers were selected for the study by a lottery method and through randomization and among them, 30 primipara mothers were allotted to experimental group by allotting even numbers, 30 primipara mothers were allotted to control group by allotting odd numbers.

Results: The mean pre test knowledge score in experimental group was $11.00 \pm 2.77$, whereas mean post test knowledge score in experimental group was $20.96 \pm 1.24$. The mean pre test knowledge score in control group was $10.60 \pm 3.30$; whereas mean post test knowledge score in control group was $11.67 \pm 1.53$. The posttest mean value knowledge score among primipara mothers in the experimental group was significantly higher than the pre test knowledge score of the primipara mothers in the same group. The paired student " $t$ " test value was 20.84 which was significant at $\mathrm{P}=0.001$ level. The findings revealed that there was significant association between knowledge score with residence and educational level of the primipara mothers in experimental group.

Conclusion: Study concluded that weaning practices should be given more weightage for overall growth of the children.
\end{abstract}

Keywords: Weaning practices, Primipara mothers, knowledge scores, learning package, paediatric OPD

\section{INTRODUCTION}

Weaning is defined as the process of giving up one method of feeding for another, weaning usually refers to relinquishing the breast or bottle for a cup. In western societies this is generally regarded as a major task for infant and is often seen as a potentially traumatic experience. It is a psychologically significant because the infant is required to give up a major source of oral pleasure and gratification $^{1}$. Response to child's signs of hunger and feeding abilities, gives help and encouragement (without forced feeding) feeding slowly and patiently, experimenting, with different foods, tastes, combination and textures, minimizing distraction, using plenty of smiles, eye contact and encouraging words, so that feeding becomes a time for learning and love $\mathrm{e}^{2}$. Breast feeding and family food: Loving and healthy. The food given should "complement ${ }^{\circ}$-make complete- with the energy and nutrients provided by breast milk. At 6-11 months period is especially a vulnerable time because infants are just learning to eat and must be fed soft food frequently and patiently ${ }^{3}$. Weaning is the stage in an 
infant's life when there is a transition from breast milk to other sources of nourishment. When to wean is a personal decision for the parent. It may be influenced by the health performance decided or simply feeding that it's the right time but it is important to understand that weaning is a gradual process that calls for patience and understanding between the infant and the mother ${ }^{4}$. If Weaning is not proper, children are likely to be malnourished. Weaning is the bridge that the mother has to form between liquid and solid diet. Weaning food should be cheap, easily available and acceptable to the custom. By one year of age the child must be taking all items that are cooked at home. This is called 'family pot feeding' ${ }^{5}$. The sources according to T.V. Sivanandan (2006), The National Rural Health Mission said that the 10th plan target would aim at reducing infant mortality rate to 45 per 1,000 live births by the year 2007 and 28 per 1,000 live births by 2012. It also aimed at reducing the maternal mortality rate to 2 per 1,000 live births by 2007 and 1 per 1,000 live births by $2012^{6}$. Suraj Gupte (2004) reported that the mother could produce sufficient breast milk to sustain the growth of infants for the first 4-6 months of age. It is necessary to introduce more concentrated nutritional supplements to the infants during that period in addition to breast milk and not instead of it. Introduction of complementary feeds too late results in an inadequate intake of energy and protein leading to poor growth and stunting as well as iron and other nutrient deficiencies $^{7}$. The high incidences of problems related to weaning in children provoked us to select the following topic for the study.

Statement of Problem: An experimental study to assess the effectiveness of learning package on weaning practices among the primipara mothers attending the paediatric OPDs at S.C. Hospital Hassan, Karnataka.

\section{Objectives}

1. To assess the level of knowledge regarding weaning of primipara mothers among control and experimental group during pre test.

2. To assess the level of knowledge regarding weaning of primipara mothers among control and experimental group after the administration of learning package.

3. To determine the weaning practices of primipara mothers among control and experimental group after the post test.

4. To associated the weaning practices of primipara mothers with selected sociodemographic variable.

\section{MATERIAL AND METHODS}

Research approach:- Quantitative approach.

Research Design:- True experimental research design (pre test and post test with control group) was used to conduct the study.

Research Setting: Study was conducted at S.C. government hospital Hasan, Karnataka. Population:- Study population consisted of all primipara mothers having infant aged between 6-12 months attending the paediatric OPDs of the S.C. Hospital Hasan, Karnataka.

Sampling technique and sample: 60 primipara mothers selected through simple random technique by a lottery method. Experimental and control group samples (each 30) were allotted through even and odd numbers.

Research Tool: The tools selected for the present study divided in two sections.

Section I:- Socio-demographic variables included 8 items such as age of the infant, Gender of the infant, residence, type of the family, religion, occupation of father, monthly family income, and educational status of the mother.

Section II:- Structured knowledge questionnaire consists of 25 questions to assess the level of knowledge regarding weaning practices. The area included were knowledge on growth and development (5 
questions), knowledge on weaning practices (12 questions) and knowledge on weaning (8 questions).

Prior to tool administration all subjects were given an information sheet, explaining the purpose and outcome of study. Informed consent was taken from participants and self explanatory tools were administered to participants. Permission for study was taken from concerned authorities.

\section{RESULTS}

According to table 1, there was equal distribution of infants age group 6-9 months and 9-12 months in control group but in experimental group $18(60 \%)$ infants were in age group of 9-12 months, equal gender distribution among both control and experimental group, $17(56.7 \%)$ samples were staying in rural area in the experimental group while 17 (56.7\%) samples were staying in urban area in the control group. In relation to type of family, $16(53.3 \%)$ belongs to joint family in experimental group while $20 \quad(66.7 \%)$ belong to joint family in control group, 19 $(63.3 \%)$ samples were Hindus in experimental group and $21(73.3 \%)$ were Hindus in control group. Parent's occupation reveals 17 (56.7\%) samples occupation was business in experimental group while $10(33.3 \%)$ samples occupation was business in control group, as per monthly income $12(40 \%)$ samples were distributed in both 10000-20000/- Rs group and 20001-30000/- Rs group in experimental group while $17(56.7 \%)$ were in 10000-20000/- Rs group in control group, $16(53.3 \%)$ of the sample had up to secondary level education in experimental group while $12(40 \%)$ of samples had up to secondary level education.

The data given in table 2 revealed that, in the experimental group $10(33.3 \%)$ of primipara mothers were having the knowledge on growth and development and in the control group on $10(33.3 \%)$ primipara mothers are having the knowledge on growth and development, in the experimental group $15(50 \%)$ of the primpara mothers are having the knowledge on weaning practices and in the control group $14(46.7 \%)$ of the primipara mothers are having the knowledge on weaning practices, in the experimental group 13 $(43.3 \%)$ of the primipara mothers are having the knowledge on weaning and in the control group $12(40 \%)$ of the primipara mothers are having the knowledge on weaning. Considering the overall knowledge, it shows that primipara mothers are having almost equal knowledge on growth and development, weaning practice and weaning there was no statistically significant difference between experimental and control group.

As per table 3 , in the experimental group $23(76.7 \%)$ of primipara mothers are having the knowledge on growth and development and in the control group 11 $(36.7 \%)$ of primipara mothers are having the knowledge on growth and development, in the experimental group $26(86.7 \%)$ of the primipara mothers are having the knowledge on weaning practice and on an average in the control group $15(50 \%)$ of the primipara mothers are having the knowledge on weaning practice, in the experimental group $25(83.3 \%)$ of the primipara mothers are having the knowledge on weaning and on an average in the control group $12(40 \%)$ of the primipara mothers are having the knowledge on weaning, Considering the overall knowledge, it shows that the primipara mothers of the experimental group are having more knowledge after attending the learning package on weaning practices than the primipara mothers of the control group who did not attend the learning package.

According to table 4 In the pre-test the primipara mothers of the experimental group had a percentage score of $43.3 \%$ and in the control group the primipara mothers had a percentage score of $40 \%$, so the difference between experimental and control group score is only $3.3 \%$ in the pre-test. Considering the overall, in post-test $83.3 \%$ score in experimental group and $43.3 \%$ score in control group primipara mothers, so 
the difference between experimental and control group score is only $40 \%$ in the posttest. This $40 \%$ difference between experimental and control group is the net benefit of experimental group primipara mothers due to the learning package.

The data in table 5 shows the pretest and post-test score on weaning practice on the overall score there is a reasonable difference between pre-test and post-test score. In the experimental group the pre-test mean score is (11.00) and standard deviation score is (2.77) and in post-test the mean score is (20.96) and standard deviation score is (1.24) and in the control group the pre-test mean score is (10.60) and standard deviation score is (3.30) and in post-test the mean score is (11.67) and standard deviation score is (1.53). This difference is statistically significant. This statistical significance between pre-test and post-test was calculated by using student paired t-test $(\mathrm{P}<0.05)$ and between the groups by using student independent t-test.

The data given in table 6 depicts that in experimental group both residence $(p=0.003)$ and level of education $(p=0.03)$ were significantly associated with knowledge gain score regarding weaning practices among primipara mothers.

\begin{tabular}{|c|c|c|c|c|c|c|}
\hline \multirow[t]{2}{*}{ S. No. } & \multirow[t]{2}{*}{ Demographic Variables } & \multicolumn{2}{|c|}{ Experimental } & \multicolumn{2}{|c|}{ Control } & \multirow[b]{2}{*}{ Total } \\
\hline & & Freq. & $\%$ & Freq. & $\%$ & \\
\hline $\begin{array}{l}1 \\
\text { a) } \\
\text { b) }\end{array}$ & $\begin{array}{l}\text { Age } \\
6-9 \text { months } \\
9-12 \text { months }\end{array}$ & $\begin{array}{l}15 \\
15 \\
\end{array}$ & $\begin{array}{l}50 \% \\
50 \% \\
\end{array}$ & $\begin{array}{l}12 \\
18 \\
\end{array}$ & $\begin{array}{l}40 \% \\
60 \% \\
\end{array}$ & $\begin{array}{l}27 \\
33 \\
\end{array}$ \\
\hline $\begin{array}{l}2 \\
\text { a) } \\
\text { b) }\end{array}$ & $\begin{array}{l}\text { Gender } \\
\text { Male } \\
\text { Female }\end{array}$ & $\begin{array}{l}15 \\
15 \\
\end{array}$ & $\begin{array}{l}50 \% \\
50 \% \\
\end{array}$ & $\begin{array}{l}15 \\
15 \\
\end{array}$ & $\begin{array}{l}50 \% \\
50 \% \\
\end{array}$ & $\begin{array}{l}30 \\
30 \\
\end{array}$ \\
\hline $\begin{array}{l}3 \\
\text { a) } \\
\text { b) }\end{array}$ & $\begin{array}{l}\text { Residence } \\
\text { Rural } \\
\text { Urban }\end{array}$ & $\begin{array}{l}17 \\
13 \\
\end{array}$ & $\begin{array}{l}56.7 \% \\
43.3 \%\end{array}$ & $\begin{array}{l}13 \\
17 \\
\end{array}$ & $\begin{array}{l}43.3 \% \\
56.7 \%\end{array}$ & $\begin{array}{l}30 \\
30 \\
\end{array}$ \\
\hline $\begin{array}{l}4 \\
\text { a) } \\
\text { b) }\end{array}$ & $\begin{array}{l}\text { Type of family } \\
\text { Nuclear } \\
\text { Joint } \\
\end{array}$ & $\begin{array}{l}14 \\
16 \\
\end{array}$ & $\begin{array}{l}46.7 \% \\
53.3 \% \\
\end{array}$ & $\begin{array}{l}10 \\
20 \\
\end{array}$ & $\begin{array}{l}33.3 \% \\
66.7 \% \\
\end{array}$ & $\begin{array}{l}24 \\
36 \\
\end{array}$ \\
\hline $\begin{array}{l}5 \\
\text { a) } \\
\text { b) } \\
\end{array}$ & $\begin{array}{l}\text { Religion } \\
\text { Hindu } \\
\text { Muslim } \\
\end{array}$ & $\begin{array}{l}19 \\
11 \\
\end{array}$ & $\begin{array}{l}63.3 \% \\
36.7 \% \\
\end{array}$ & $\begin{array}{l}22 \\
08 \\
\end{array}$ & $\begin{array}{l}73.3 \% \\
26.7 \% \\
\end{array}$ & $\begin{array}{l}41 \\
19 \\
\end{array}$ \\
\hline $\begin{array}{l}\text { 6. } \\
\text { a) } \\
\text { b) } \\
\text { c) } \\
\text { d) }\end{array}$ & $\begin{array}{l}\text { Occupation } \\
\text { Private } \\
\text { Government } \\
\text { Business } \\
\text { Others } \\
\end{array}$ & $\begin{array}{l}03 \\
02 \\
17 \\
08 \\
\end{array}$ & $\begin{array}{l}10.0 \% \\
6.7 \% \\
56.7 \% \\
26.7 \% \\
\end{array}$ & $\begin{array}{l}09 \\
03 \\
10 \\
08 \\
\end{array}$ & $\begin{array}{l}30.0 \% \\
10.0 \% \\
33.3 \% \\
26.7 \% \\
\end{array}$ & $\begin{array}{l}12 \\
05 \\
27 \\
16\end{array}$ \\
\hline $\begin{array}{l}7 . \\
\text { a) } \\
\text { b) } \\
\text { c) } \\
\text { d) }\end{array}$ & $\begin{array}{l}\text { Monthly Income } \\
\text { 10000-20000Rs. } \\
\text { 20001-30000Rs. } \\
\text { 30001-40000Rs. } \\
\text { >40001Rs. }\end{array}$ & $\begin{array}{l}12 \\
12 \\
04 \\
02\end{array}$ & $\begin{array}{l}40.0 \% \\
40.0 \% \\
13.3 \% \\
6.7 \% \\
\end{array}$ & $\begin{array}{l}17 \\
09 \\
02 \\
02 \\
\end{array}$ & $\begin{array}{l}56.7 \% \\
30.0 \% \\
6.7 \% \\
6.7 \% \\
\end{array}$ & $\begin{array}{l}29 \\
21 \\
06 \\
04\end{array}$ \\
\hline $\begin{array}{l}8 . \\
\text { a) } \\
\text { b) } \\
\text { c) } \\
\text { d) } \\
\text { e) }\end{array}$ & $\begin{array}{l}\text { Education } \\
\text { Primary } \\
\text { Middle } \\
\text { Secondary } \\
\text { Higher Secondary } \\
\text { Graduate }\end{array}$ & $\begin{array}{l}02 \\
08 \\
16 \\
03 \\
01\end{array}$ & $\begin{array}{l}6.7 \% \\
26.7 \% \\
53.3 \% \\
10.0 \% \\
3.3 \% \\
\end{array}$ & $\begin{array}{l}06 \\
08 \\
12 \\
03 \\
01\end{array}$ & $\begin{array}{l}20 \% \\
26.7 \% \\
40 \% \\
10 \% \\
3.3 \% \\
\end{array}$ & $\begin{array}{l}08 \\
16 \\
28 \\
06 \\
02\end{array}$ \\
\hline
\end{tabular}

Table: 2- Pre test level of knowledge on weaning practices among primipara mothers in experimental and control group.

\begin{tabular}{|l|l|l|}
\hline \multirow{2}{*}{ Level of knowledge among primipara mothers on weaning practices } & Correct response \\
\cline { 2 - 3 } & Experimental $(\mathbf{n}=\mathbf{3 0})$ & Control $(\mathbf{n}=\mathbf{3 0})$ \\
\hline Knowledge of growth and development & $10(33.3 \%)$ & $10(33.3 \%)$ \\
\hline Knowledge on weaning practices & $15(50 \%)$ & $14(46.7 \%)$ \\
\hline Knowledge on weaning & $13(43.3 \%)$ & $12(40 \%)$ \\
\hline Average no. of primipara mothers & $13(43.3 \%)$ & $12(40 \%)$ \\
\hline
\end{tabular}

Table 3 Post test level of knowledge on weaning practices among primipara mothers in experimental and control group

\begin{tabular}{|l|l|l|}
\hline Level of knowledge among primipara mothers on weaning practices & Correct response \\
\cline { 2 - 3 } & Experimental $(\mathbf{n}=\mathbf{3 0})$ & Control $(\mathbf{n}=\mathbf{3 0})$ \\
\hline Knowledge of growth and development & $23(76.7 \%)$ & $11(36.7 \%)$ \\
\hline Knowledge on weaning practices & $26(86.7 \%)$ & $15(50 \%)$ \\
\hline Knowledge on weaning & $25(83.3 \%)$ & $12(40 \%)$ \\
\hline Average no. of primipara mothers & $25(83.3 \%)$ & $13(43.3 \%)$ \\
\hline
\end{tabular}


Table: 4 Comparison of percentage of difference between pre-test and post-test in experimental and control group

\begin{tabular}{|l|l|l|l|}
\hline \multirow{2}{*}{ Level of knowledge among primipara mothers on weaning practices } & Correct response & Difference \\
\cline { 2 - 4 } & Experimental $(\mathbf{n}=\mathbf{3 0})$ & Control (n=30) & ( \\
\hline Pre test & & & \\
\hline Knowledge of growth and development & $33.3 \%$ & $33.3 \%$ & 00 \\
\hline Knowledge on weaning practices & $50 \%$ & $46.7 \%$ & $3.3 \%$ \\
\hline Knowledge on weaning & $43.3 \%$ & $40 \%$ & $3.3 \%$ \\
\hline Overall pre-test & $43.3 \%$ & $40 \%$ & $3.3 \%$ \\
\hline Post test & & & \\
\hline Knowledge of growth and development & $76.7 \%$ & $36.7 \%$ & $40.0 \%$ \\
\hline Knowledge on weaning practices & $86.7 \%$ & $50 \%$ & $36.7 \%$ \\
\hline Knowledge on weaning & $83.3 \%$ & $40 \%$ & $43.3 \%$ \\
\hline Overall post-test & $83.3 \%$ & $43.3 \%$ & $40.0 \%$ \\
\hline
\end{tabular}

Table: 5 Comparison of mean knowledge score between pre-test and post-test in experimental and control group

\begin{tabular}{|l|l|l|l|}
\hline Knowledge score & Pre test Mean \pm SD & Post test Mean \pm SD & Student paired t-test \\
\hline Experimental & $11.0 \pm 2.77$ & $20.96 \pm 1.24$ & $\begin{array}{l}\mathrm{t}=20.84 \\
\mathrm{P}=0.001 \\
\text { Significant }\end{array}$ \\
\hline Control & $10.60 \pm 3.30$ & $11.67 \pm 1.53$ & $\begin{array}{l}\mathrm{t}=1.67 \\
\mathrm{P}=0.11 \\
\end{array}$ \\
& & & Not Significant \\
\hline Student Independent t-test & $\mathrm{t}=0.50$ & $\mathrm{t}=18.02$ & \\
& $\mathrm{P}=0.62$ & $\mathrm{P}=0.001$ & \\
& Not Significant & Significant & \\
\hline
\end{tabular}

Table 6 Association between post test knowledge gain score and socio-demographic variables of primipara mothers in experimental group.

\begin{tabular}{|c|c|c|c|c|c|c|}
\hline Variable & & Freq. & Pre-test Mean & Post-test Mean & Gain Score & Statistical inference \\
\hline \multirow[b]{2}{*}{ Residence } & Rural & 17 & 11.29 & 19.88 & 8.47 & \multirow{2}{*}{$\begin{array}{l}\mathrm{t}=3.28 \\
\mathrm{p}=0.003 \\
\text { Significant } \\
\text { (Student independent } \mathrm{t} \text {-test) }\end{array}$} \\
\hline & Urban & 13 & 10.29 & 22.07 & 11.61 & \\
\hline \multirow{5}{*}{$\begin{array}{l}\text { Level } \\
\text { of Education }\end{array}$} & Primary & 2 & 7.00 & 20.50 & 13.50 & \multirow{5}{*}{$\begin{array}{l}\mathrm{F}=3.13 \\
\mathrm{p}=0.03 \\
\text { Significant } \\
\text { (One way ANOVA F-test) }\end{array}$} \\
\hline & Middle & 8 & 13.00 & 22.37 & 9.37 & \\
\hline & Secondary & 16 & 11.07 & 20.75 & 9.68 & \\
\hline & High. Sec. & 3 & 10.30 & 23.63 & 13.33 & \\
\hline & Graduation & 1 & 10.00 & 24.00 & 14.00 & \\
\hline
\end{tabular}

\section{DISCUSSION}

According to table 2, our study revealed that primipara mothers were having almost equal knowledge in both experimental group $13(43.3 \%)$ and control group $12(40 \%)$ in their pre test and that was found to be inadequate in the both groups. Our findings supported by a study conducted by Kambli S. $(2014)^{8}$ in which she revealed that majority of the mothers were having wrong concept about weaning and are not knowledgeable about current weaning recommendations. Our findings also supported by a study conducted by Leelavathi A. $(2019)^{9}$ and Graham V.A. et al $(1998)^{10}$.

As per table 3 we found that the knowledge of the primipara mothers in the experimental group $25(83.3 \%)$ increased after attending the learning package on weaning practices. Our findings supported by studies conducted by Kadli Sam Prasad
$(2019)^{11}$ \& Raj, E.V. et al (2016) ${ }^{12}$ with similar findings.

According to table 4 we found that there was difference between experimental and control group's pre-test knowledge score regarding weaning practices was only $3.3 \%$. But in post-test $83.3 \%$ score in experimental group and $43.3 \%$ score in control group. This $40 \%$ difference between experimental and control group is the net benefit due to the learning package. The difference between experimental and control group was also supported by studies conducted by Kaur Rajveer et al $(2019)^{13}$ on breastfeeding.

Data in table 5 revealed statistically significant difference between pre test and post test knowledge score after learning package in experimental group which was calculated by using student paired t-test $(\mathrm{P}<0.05)$. Our findings supported by studies conducted by Dhanani Pooja et al $(2021)^{14}$ \& Batra B (2019) $)^{15}$ with similar findings. 
According to table 6 we found that there was significant association between knowledge gain score and socio demographic variables like residence $(\mathrm{p}=$ $0.003)$ and level of education $(p=0.03)$. Our study finding supported by a study conducted by Beautily $\mathrm{V}^{16}$ in which she found significant association between knowledge gain score and level of education. Kumari R. et al (2018) ${ }^{17}$ also find the similar result with level of education and knowledge level.

\section{CONCLUSION}

Findings of our study strongly recommend the need for conducting nursing education program to increase the knowledge on weaning practice among primipara mothers. Educating mothers and providing them correct information can help them to know about weaning practices.

Limitations: The small size (60) of the sample made it difficult to draw generalization. A structured questionnaire was used for data collection which restricts the amount of information that can be obtained from the respondents, only knowledge was assessed; no attempt was made to assess their attitudes and practice due to time shortage and less resources.

Source of Funding: Researcher had selffinanced the present study.

Conflict of Interest: There was no conflict of interest involved while conducting the present study.

\section{Acknowledgement: None}

\section{Ethical Approval: Approved}

\section{REFERENCES}

1. Wong, D. L., Hockenberry, M. J., Wilson, D., \& Winkelstein, M. L. Wong's essentials of pediatric nursing (7th ed.). St. Louis, Mo.: Elsevier Mosby: 2006. p.no.331-332

2. C.Williams. Breast feeding and family foods: Loving and Healthy. WABA World Breastfeeding Week 2005: p.no. 1-11.
Available from https://www.waba.org.my/whatwedo/wbw/ wbw05/actionfolder.pdf

3. Breast feeding promotion network of India. Introducing solids. Complimentary feeding). www.bpni.org.

4. Barbara P. Homeier, M.D. updated and reviewed weaning.2002 August,

5. K.E. Elizabeth. Fundamental of paediatrics. 1st edition, Jaypee Brothers; 2001.p.no.4850

6. T.V. Sivanandan. The National Rural Health Mission.2006

7. Suraj Gupte. The short test book of paediatrics. 10th edition, Jaypee Brothers; 2006. p.no 13.

8. Kambli S. Mother's Knowledge Regarding Weaning Process in Infants. International Journal of Science and Research (IJSR).Volume 3 Issue 7, July 2014.

9. Leelavathi A. A Descriptive Study to Assess the Level of Knowledge Regarding Weaning Among Primipara Mothers of Infants.Journal of Perinatal, Pediatric and Neonatal Nursing.Volume 1 Issue 2.2019.

10. Graham V.A. et al. Filling the gap: Weaning practices of children aged 0-2 years in western metropolitan Melbourne. J Pediatric child health.1998 Dec: 34(6); 513-7.

11. Kadali Sam Prasad. Effectiveness of Video Assisted Teaching Programme on knowledge regarding weaning among mothers of Infant. Int. J. Nur. Edu. and Research. 2019; 7(3):325-326. doi: 10.5958/2454-2660.2019.00073.5

12. Raj, E.V. \& Suresh, Geetha. (2016). Effectiveness of STP on knowledge regarding weaning among primi-para mothers. The Journal of Nursing Trendz. 7. 14. 10.5958/2249-3190.2016.00030.4.

13. Kaur R, Packia G, Kaur A et.al. A study to assess the effectiveness of educational package on knowledge regarding breast milk expression and its storage among working lactating mothers. Int J Health Sci Res. 2019; 9(9):91-98.

14. Dhanani Pooja L., K. Sam Prasad S., Jeenath Justin Doss. K.. A Study to Assess the Effectiveness of Planned Teaching Programme on Knowledge regarding Weaning among Primigravid Mothers in selected rural area at Bhuj, Gujarat. Asian J. Nursing Education and Research. 2021; 11(1):133-135. doi: 10.5958/23492996.2021.00034.3 Available on: 
https://ajner.com/AbstractView.aspx?PID=2 021-11-1-34

15. Batra B, Singh A. A Study to Assess the Effectiveness of Planned Teaching Program on Knowledge Regarding Weaning among Mothers of Infants in a Selected Area of Rewa City. Int J Nurs Med Invest. 2019; 4(2):28-30

16. Beautily V. A study to assess the knowledge on weaning practice among postnatal mothers. IJRPS.

DOI: https://doi.org/10.26452/ijrps.v11i3.2519
17. Kumari R. Butter BK. A study to assess the knowledge of mothers of infants regarding weaning from selected area of Dadwan, Gurdaspur. International Journal Of Research Science \& ManagemenT. 5(6):June, 2018]. $\quad$ DOI: 10.5281/zenodo. 1291894

How to cite this article: Tak HK, Chaturvedi D. Effectiveness of learning package on weaning practices among primipara mothers. Int $J$ Health Sci Res. 2022; 12(1): 229-235. DOI: https://doi. org/10.52403/ijhsr.20220131 